\title{
The Snow Dragon: China's Strategies in the Arctic
}

\section{Olga Alexeeva and Frédéric Lasserre}

\section{OpenEdition}

\section{Journals}

\section{Electronic version}

URL: http://journals.openedition.org/chinaperspectives/5958

DOI: 10.4000/chinaperspectives.5958

ISSN: 1996-4617

\section{Publisher}

Centre d'étude français sur la Chine contemporaine

\section{Printed version}

Date of publication: 1 October 2012

Number of pages: 61-68

ISSN: 2070-3449

\section{Electronic reference}

Olga Alexeeva and Frédéric Lasserre, «The Snow Dragon: China's Strategies in the Arctic », China Perspectives [Online], 2012/3 | 2012, Online since 01 October 2015, connection on 28 October 2019. URL : http://journals.openedition.org/chinaperspectives/5958 ; DOI : 10.4000/chinaperspectives.5958 


\title{
The Snow Dragon:
}

\section{China's Strategies in the Arctic}

\author{
OLGA V. ALEXEEVA AND FRÉDÉRIC LASSERRE
}

\begin{abstract}
In recent years, several analyses and news media articles have predicted a resurgence of tensions in the Arctic over access to maritime space. Among the contenders involved in this potential struggle is China, whose ambitions in the region are suspected to hold a destabilising potential. Yet, as Beijing is developing its policy towards the region, it remains unclear whether it will contest the claims over maritime access of countries bordering the Arctic and forcibly take over parts of the region for resource extraction purposes.
\end{abstract}

\section{KEYWORDS: China, Arctic, strategy, geopolitics, natural resources, Sino-Russian partnership.}

$\mathrm{n}$ recent years, the Arctic region has aroused increasing international interest. This interest has predominantly been reflected in extensive media coverage bringing attention to the area's abundant resources, border-related stakes, and the possible opening of new maritime routes. ${ }^{(1)}$ Located north of the polar circle, the region comprises a large number of seas, and borders eight countries. Among the latter, five are located along the Arctic Ocean - Canada, Russia, the United States, Norway, and Denmark (via Greenland). (2) New climatological conditions have created promising geostrategic opportunities for countries bordering the region, anticipating that the creation of a new trade route from north to east could lead to significant commercial profits and increase access to natural resources for economic growth purposes. As implied by extant analyses, such a route would be shorter and would facilitate trade flows compared to existing alternatives via the Suez Canal. (3)

Yet, interest in the region does not stop at circumpolar states. Other countries see a number of geostrategic opportunities and stakes involved in accessing the Arctic. China, which lacks a legal basis to articulate claims over access to the region, has nonetheless been increasingly present. ${ }^{(4)}$ In recent years and despite a lack of experience in researching the area, Beijing has succeeded in conducting a vast scientific Arctic research program in the fields of climatology, geology, and biology, among others. Moreover, Beijing has mobilised considerable efforts towards the building of political and economic ties with smaller Arctic countries such as Norway and Iceland, and has brought Arctic-related questions to its diplomatic agenda with Russia and Canada. (5)

These efforts on the part of China since 2009 have engendered negative reactions on the part of the Western media, which portray China as ambitious, greedy, and ready to conquer and threaten the territorial sovereignty of countries in the Arctic region. Examples commonly cited of such attempts include the sudden appearance of China's research icebreaker in Tuktoyaktuk (Northwest Territories, Canada) in 1999. Claims that the icebreaker's presence was unexpected served as a pretext to accuse China of suspect motivations in the area. ${ }^{(6)}$ Yet in reality the Chinese government had submitted to the Canadian Embassy in Beijing a formal request to enter the area. ${ }^{(7)}$ Chinese admiral Yin Zhuo's assertion that arctic resources are a world heritage ${ }^{(8)}$ was nonetheless cited as evidence of the duplicity of the Chinese government, whose ambitions in the Arctic would threaten the interests of Canada and other countries bordering the region. (9)

Discussions over potential natural resource reserves in the area and the opening of new trade routes have led to multiple speculation over the intentions of regional and world powers, increasingly concerned about their economies' dependence on energy security. In the context of these debates, our analysis provides a general overview of China's scientific and political presence in the Arctic, as well as its official policy and potential future strategies towards the latter.

1. Arvind Gupta, "Geopolitical implications of Arctic meltdown," Strategic Analysis, vol. 22, no. 2, 2009, pp. 174-177; Stephanie Holmes, "Breaking the Ice: Emerging Legal Issues in Arctic Sovereignty," Chicago Journal of International Law, vol. 9, no. 1, 2008, pp. 323-352; Frédéric Lasserre (ed.), Passages et mers arctiques. Géopolitique d'une région en mutation (Arctic corridors and seas: Geopolitics in a region undergoing change), Quebec, University of Quebec Press, 2010.

2. Iceland, located in the north of the Atlantic Ocean, is not considered to border the Arctic by member countries of the Arctic Council.

3. Ju. A. Evdokimov, Ju. M. Backih, A.V. Istomin, "S Severnyj morskoj put': problemy, vozmožnosti, perspektivy vozroždenija (The Northern Sea Route: Problems, opportunities, revival prospects), Ėkonomičeskaja nauka sovremennoj Rossii (Economics of Contemporary Russia), vol. 2, 2000, Pp. 101-112; Li Zhenfu, "Beiji hangxiande Zhongguo zhanluë fenxi" (Analysing China's strategy with respect to the Northern Sea Route), Zhongguo ruankexue, no. 1, 2009, pp. 1-7; Fréderic Lasserre, "Géopolitiques arctiques : pétrole et routes maritimes au cœur des rivalités régionales ?", Critique Internationale, vol. 49, 2010, pp. 131-156; V. Peresipkin, A. Jakovlev, "Severnyj morskoj put' $v$ probleme meždunarodnyh transportnyh koridorov" (The Northern Sea Route in international transport networks), Transport Rossijskoj Federacii (Russian federation transport), no. 3, 2006, pp. 30-35.

4. Ministry of Foreign Affairs of the People's Republic of China (2010), China's View on Arctic Cooperation, 2010, www.fmprc.gov.cn/eng/wjb/zzjg/tyfls/tfsxw/t812046.htm (consulted on 7 August 2012).

5. Ministry of Foreign affairs of the People's Republic of China, "Director General Huang Huikang Meets with Canadian Assistant Deputy Minister of Foreign Affairs Christie," 2011, www.fmprc.gov.cn/eng/wjb/zygy/gyhd/t858972.htm (consulted on 7 August 2012).

6. "Who Will Guard Our Gaping Back Door?", Edmonton Journal, 18 November 2007.

7. Nancy Teeple, "A Brief History of Intrusions into the Canadian Arctic," Canadian Army Journal, vol. 12, no. 3, 2010, pp. 45-68.

8. Gordon Chang, "China's Arctic Play," The Diplomat, 2010, http://thediplomat.com/2010/03/09/ china\%E2\%80\%99s-arctic-play (consulted on 7 August 2012).

9. Curtis David Wright, "The Panda Bear Readies to Meet the Polar Bear: China Debates and Formulates Foreign Policy Towards Arctic Affairs and Canada's Arctic Sovereignty," Canadian Defence \& Foreign Affairs Institute Papers, 2011, http://www.cdfai.org/PDF/The\%20Panda\%20Bear\%20Readies\%20to\% 20Meet\%20the\%20Polar\%20Bear.pdf (consulted on 8 August 2012). 


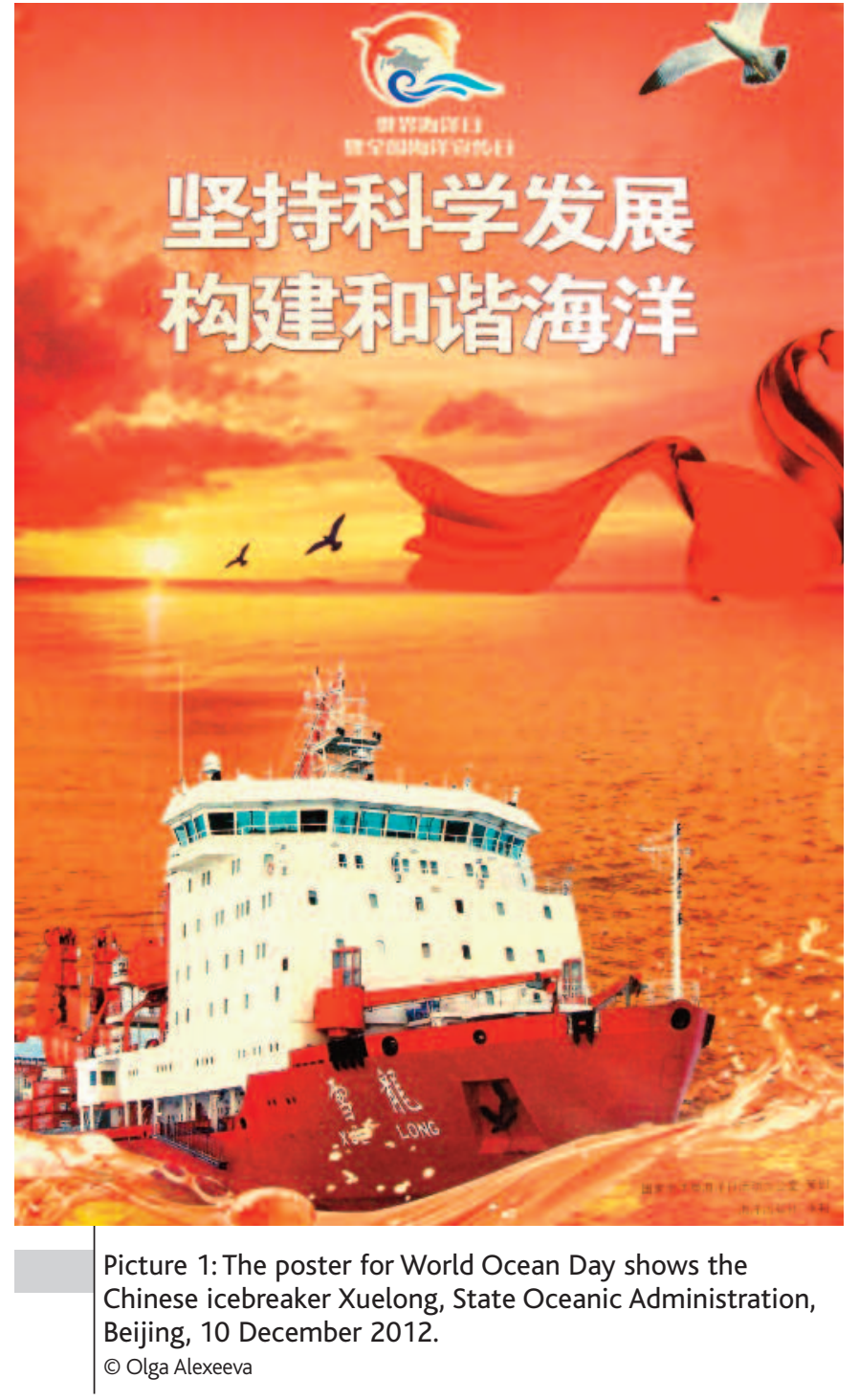

\section{China's presence in the Arctic}

Until recently, China's growing presence in the Arctic remained unnoticed, even in a context of increasing international competition for control over the region as a result of climate change. In spite of a number of reports and news media articles covering the topic, few academic studies had been dedicated to China's policy priorities in the Arctic. ${ }^{(10)} \mathrm{A}$ report published by the Stockholm International Peace Research Institute (SIPRI) in 2010 entitled "China Prepares for An Ice-free Arctic" (11) was one of the first studies to address the issue. It attracted considerable attention on the part of an international community becoming aware of China's aspiration to become one of the main geopolitical actors in the Arctic and to take an active part in the management of its natural resources.

Moreover, searches in China's largest database, Wanfang Data, (12) revealed that more than a hundred studies by mainland Chinese researchers had already been published on the Arctic region across a number of disciplines. While articles published between 1996 and 2008 predominantly pertained to ecology-related matters (i.e., climate change and temperature shifts in the Arctic, biodiversity, etc.), ${ }^{(13)}$ publications in the past five years have mostly touched on the role that the region could play in China's future economic growth and geostrategic interests. ${ }^{(14)}$

\section{A significant polar research program}

China's interest in the Arctic was not exclusively manifested by an increase in academic studies on the region, but was also reflected in its expanding presence in the area. In 1992, before the possibility of new trade routes in the region was even raised, Beijing had organised jointly with the German universities of Kiel and Bremen its first five-year scientific research program in the Arctic Ocean. This project was subsequently followed by China's entry into the International Arctic Science Committee (IASC) in 1996. Founded in 1990, the organisation is comprised of 18 countries, and its main mission consists of promoting research cooperation on the Arctic. The main objective of the Chinese research program in the area has been the study of interactions between the Ice Arctic Ocean, sea ice, and the atmosphere. With the help of a supporting database and some samples, China has also sought to learn more about the impact of abnormal temperature changes in the North Pole on China's climate. ${ }^{(15)}$

The purchase in the Ukraine in 1994 of an icebreaker (polar class $5^{(16)}$ ) called Xuelong 雪龙, or Snow Dragon, ${ }^{\left({ }^{17}\right)}$ enabled China to become one of the active independent researchers in the polar area, and to organise a large number of scientific expeditions in the Arctic and Antarctic (see picture 1). Coordinated by the Chinese Arctic and Antarctic Administration (CAA), ${ }^{(18)}$ these research projects have reached a significant scale. In addition to 27 expeditions in the Antarctic, China has conducted four expeditions in the Arctic (in 1999, 2003, 2008, and 2010). It has also founded its first station in 2004. Called Yellow River (黄河), the station is located in Ny-Alesund on the Island of Spitsbergen in Norway. In 2009, the Chinese government made the decision to improve its fleet's capacity by launching the industrial production of Chinese icebreak-

10. Frédéric Lasserre, "China and the Arctic: Threat or Cooperation Potential for Canada?", CIC China Papers, no. 11, 2010

11. Linda Jakobson, "China Prepares for an Ice-Free Arctic," SIPRI Insights on Peace and Security, no. 2, 2010, http://books.sipri.org/files/insight/SIPRIInsight1002.pdf (consulted on 8 August 2012).

12. Wanfang Data is China's first database, created in the 1950 s by the Institute of Scientific \& Technological Information of China (ISTIC). It originally served the purpose of digitalising information about companies and their products. It was later transformed into a vast electronic database of multidisciplinary information, and provides access to many collections of periodicals, theses, and other types of archives. See www.wanfangdata.com.cn (consulted on 9 August 2012).

13. See for example, Yan Qide, "Beiji diqu yu quanqie bianhua" (Arctic and global change), Kexue, vol. 57, no. 3, 2005, pp. 14-17; Chen Liji, "Nanji he Beiji diqu zai quanqiu bianhuazhongde zuoyong yanjiu" (Studying the role of the Arctic and Antarctic in global change), Dixue qianyuan (Earth science frontiers), vol. 9, no. 2, 2002, pp. 245-253.

14. Ren Xiaowei, Li Yongqiang, "Beibingyang zhuquan zhi jue yu Zhongguo guoji zeren xianxi" (Analysing sovereignty problems in the Arctic Ocean and China's international responsibility in that respect), Lanfang shifan xueyuan xuebao, vol. 24, no. 4, 2008, pp. 66-69; Shi Chunlin, "Beibingyang hangxian kaitong dui Zhongguo jingji fazhande zuoyong ji Zhongguo liyong duice" (The use and role of trade routes in the Arctic for China's economic development), Jingji wenti tansuo, no. 8, 2010, pp. 47-52.

15. Chen Liji et al.,"Yingxiang Beiji diqu xunshu bianhuade yixie guanjian guocheng yanjiu" (Studying the main factors influencing rapid changes in the Arctic), Jidi yanjiu (Chinese journal of polar research), vol. 15, no. 4, 2003, pp. 283-302.

16. According to new classification norms by the International Association of Classification Societies (IACS), ice strengthened vessels or icebreakers are ranked from 7 (minimal navigation capacity in ice) to 1 (ship capable of navigating all year in polar waters).

17. Xuelong is the first icebreaker used by China for scientific purposes in Arctic and Antarctic waters. The first one, called Xiangyanghong 10, was to fulfil many functions, such as the surveillance of missile test launches. It was also meant to be used as a weather ship and as an intermediate for long-distance communication. It was replaced in 1986 by an identical ship that was built in Finland and gave way to Ji Di. See Gilles Barnichon, Brise-glace du passage du nord-est et de la Baltique (Icebreaker in the Northeast and Baltic Passage), La Falaise, Babouji Publishers, 2011.

18. Created in 1981, this organisation was called the Office of the National Antarctic Research Expeditions Committee. It has five sections that manage all of China's activities with respect to the Arctic and Antarctic. It has several offices overseas, including Chile and in Australia. It also has a training centre in Yabuli, Heilongjiang. See the website of the Chinese Arctic and Antarctic Administration, www.chinare.gov.cn/en/index.html (consulted on 29 June 2012). 
ers. The first flagship will be built by 2013. It will be an 8,000-ton vessel and will be able to break through 1.5 metres of ice (polar class 4). ${ }^{(19)}$

\section{China's economic diplomacy towards Scandinavian countries and Russia}

In conjunction with the above scientific initiatives, the Chinese government has developed several political and economic partnerships with Arctic countries, including Norway in 2001, Denmark in 2010, and Iceland in 2010. While China has been actively developing bilateral cooperation with most European countries, it has placed a particular emphasis on Scandinavian countries given the importance of their markets. Cooperative agreements were signed mainly in the areas of Arctic navigation, natural resource extraction, academic exchanges, and joint research. Furthermore, agreements resulted in support for China's application to become a permanent observer at the Arctic Council, a regional intergovernmental forum that promotes cooperation and exchanges among Arctic countries. ${ }^{(20)}$ While the application was submitted in 2007, it was reviewed by the Council in 2009, along with those of South Korea and the European Union. Norway, Canada, and Russia rejected the European Union's demand and granted the other two countries the temporary status of ad hoc observers pending the next review of applications. Since then, Beijing has conducted an intensive diplomatic and economic self-promotion campaign among Scandinavian countries. It has emphasised the importance of a partnership, particularly in the area of natural resource extraction. Sweden, Denmark, and Iceland have expressed their full support to the integration of China within the Arctic Council. While Norway initially expressed greater restraint vis-à-vis China's integration, especially following the controversy regarding the 2010 Nobel Peace Prize awarded to Chinese dissident Liu Xiaobo, it nonetheless confirmed that it would support China's application. (21)

In May 2010, Denmark hosted a first delegation of Chinese investors and entrepreneurs. The latter signed multiple contracts and letters of intention in the areas of energy, green economy, agriculture, and food security. The total value of such agreements was estimated at US\$740 million. ${ }^{(22)}$ China also seeks to expand its mining activities in Greenland. Starting in 2015, the British corporation London Mining plans to produce an annual amount of 15 million tons of iron ore concentrate (magnetite) originating from Isua's mine, in partnership with Sinosteel and China Communications Construction Corp. Greenland Minerals and Energy has estimated that the Kvanefjeld Mine could produce 20 percent of the demand in rare earth elements and significant amounts of uranium starting in 2016. (23) Kvanefjeld's ability to influence world market prices makes it a strategic project for Chinese corporations such as Inner Mongolia Baotou Steel Rare Earth, which has already reached the status of number one rare earth element producer. (24)

Ever since the financial crisis hit Iceland in 2008, China has taken advantage of the Icelandic government's desperation in a context of financial strain to extend its role in the economic life of the country. ${ }^{(25)}$ Beijing's financial help was considered invaluable by the current President of Iceland, Ólafur Ragnar Grímsson, who has visited China five times in the past six years and has promoted Iceland as a potential transhipment centre for transport in the Arctic. ${ }^{(26)}$ China has expressed interest in the Icelandic project. (27)

In April 2012, Chinese Prime Minister Wen Jiabao went to Sweden and Iceland with the purpose of strengthening economic cooperation and getting political support for China's application for permanent observer status in the Arctic Council. (28) The diplomatic visit took place following Denmark's promise to support China. ${ }^{(29)}$ The rising economic presence of China in Iceland and Denmark has led to extensive media coverage and concern. This was particularly the case when Huang Nubo, a rich Chinese entrepreneur, revealed a significant project of purchasing real estate in Iceland in November 2011. (30) Yet China's economic cooperation with the Arctic's two major regional actors, Canada and the United States, remains limited. China invests more extensively in Canada's northern region than it does in its Arctic area. Among the locations it targets are Alberta's oil sands, as well as iron mines in Lake Otelnuk and Lake Duncan in Quebec. The Chinese corporation Jilin Jien has also invested in the Kangiqsujuaq nickel mine in Nunavik, Quebec. Washington does not seem as preoccupied with China's interest in the Arctic as it is concerned by Beijing's rising military capacity in East Asia.

Beijing's cooperation with Russia is increasing in the energy sector. ${ }^{(31)} \mathrm{Co}$ operation in the Arctic is at the heart of Sino-Russian relations and has been raised in the context of bilateral discussions about strategic and energy-related partnerships. Russia controls the Northeast Passage and plans to start large-scale natural resource extraction in the Arctic region in the short term. Moscow views China as a possible investment partner in the implementation of this project. However, resource extraction requires advanced technological expertise as well as adapted equipment (i.e., drilling rigs), both of which Russia and China lack. As the Director of the China Arctic and Antarctic Administration, Qu Tanzhou, emphasised, (32) China would only be able

19. Wang Qian, "New icebreaker to improve China's polar research," China Daily, 14 November 2011, www.chinadaily.com.cn/cndy/2011-11/04/content_14034714.htm (consulted on 8 August 2012).

20. Timo Koivurova, "Limits and possibilities of the Arctic Council in a rapidly changing scene of Arctic governance," Polar Record, vol. 46, no. 2, 2009, pp. 146-156.

21. "Despite Nobel tiff, Oslo backs China Arctic Council entry," Terra Daily, 14 February 2012, www.terradaily.com/reports/Despite_Nobel_tiff_Oslo_backs_China_Arctic_Council_entry_999.html (consulted on 8 August 2012).

22. Ministry of Foreign Affairs of the People's Republic of China, China-Denmark Bilateral Relations, 2011, www.fmprc.gov.cn/eng/wjb/zzjg/xos/gjlb/3281(consulted on 8 August 2012).

23. "Denmark Gives Access to Arctic Minerals, Rare Earths to China," International Business Times, 2012, http://au.ibtimes.com/articles/284118/20120119/denmark-gives-access-arctic-mineralsrare-earths.htm (consulted on 7 August 2012).

24. China already produces 90 percent of the world's rare earth elements. See Andrew Erickson, Gabe Collins, "China Real Time Report," Wall Street Journal, 2012, http://blogs.wsj.com/chinarealtime/ 2012/01/18/china\%E2\%80\%99s-new-strategic-target-arctic-minerals (consulted on 7 August 2012).

25. In January 2012, China promised to support Iceland's financial stability and its economic growth. See China's Government Official Portal, 2012, http://english.gov.cn/2012-01/17/ content_2046830.htm (consulted on 18 April 2012). Russia also intervened to help Iceland. Moscow initially planned to give Iceland a loan of approximately 4 billion euros in October 2008. That amount was reduced to $\$ 500$ million subsequently. Ultimately, Moscow withdrew its offer in October 2009 when Iceland agreed to a standby arrangement with the IMF and Scandinavian countries.

26. Iceland Government, Breaking the Ice:Arctic Development and Maritime Transportation. Prospects of the Transarctic Route - Impact and Opportunities, Akureyri, 2007.

27. Andrew Ward, Leslie Hook, "Iceland's president welcomes Chinese interest," Financial Times, 2011, http://www.ft.com/intl/cms/s/0/4716d5c2-d57f-11e0-9133-00144feab49a.html\# axzz23U330MVB (consulted on 7 August 2012).

28. "More Chinese pressure on Arctic Council," Barents Observer, 2012, http://barentsobserver.com/ en/arctic/more-chinese-pressure-arctic-council (consulted on 8 August 2012).

29. "Denmark welcomes China in from the Arctic cold," Reuters, 2011, http://www.reuters.com/article/2011/10/28/us-china-arctic-idUSTRE79R28S20111028 (consulted on 8 August 2012).

30. While this project was not carried through, journalists have depicted it as an attempt by China to secure itself a strategic stronghold in the Arctic. See Zhang Yunlong, Ren Qinqin, "China defends Arctic research," Xinhua, 2012, http://news.xinhuanet.com/english/china/2012-01/31/c_ 122637030.htm (consulted on 8 August 2012).

31. For greater detail on Sino-Russian cooperation, see Nikita Perfil'ev, "Perspektivi i problemy rossijsko-kitajskogo neftegazovogo sotrudničestva" (Perspectives on Sino-Russian oil and gas cooperation), Indeks bezopasnosti (Security index), vol. 14, no. 1, 2008, pp. 37-54; L. Jakobson, P. Holtom, D. Knox, J. Peng, "China's Energy and Security Relations with Russia," SIPRI Policy paper, no. 29, 2011, pp. 1-43.

32. Robert Sullivan, "Unmasking China's Arctic Gas ambitions," Natural Gas Daily, 15 March 2012, p. 9. 
to extract hydrocarbon in the Arctic with industrial cooperation agreements. Finally, China and Russia have launched a joint research program to address technical and technological problems pertaining to the construction of pipelines in Arctic and subarctic conditions. ${ }^{(33)}$

Our close look at academic analyses published by mainland scholars and our overview of Beijing's scientific activities and diplomatic initiatives in recent years reveal China's growing interest in the Arctic region. Our findings also suggest that Beijing is developing a long-term strategy that will enable it to build itself a political and a logistical base for the promotion of its interests in the Arctic.

\section{China's official stance on the Arctic}

What is Beijing's official position vis-à-vis the Arctic? To what extent are China's recent initiatives and official declarations part of a broader strategy aimed at promoting China's economic, scientific, and military development, and facilitating its access to energy and new trade routes? If a coherent strategy exists, what are its main components?

Official representatives' speeches on the Arctic have been expressed with caution and pertain mostly to climate change and environmental problems. (34) These declarations reflected China's willingness to take an active part in the process of internationalising cooperation in the Arctic. ${ }^{(35)}$ China's argument in favour of the latter is based on the United Nations' Convention United Nations Convention on the Law of the Sea (UNCLOS, 1982), which was put into place in 1994. UNCLOS states that high sea areas of the Arctic Ocean are located 200 nautical miles $(320 \mathrm{~km})$ beyond the coast of its bordering countries. These 200 miles are part of each bordering country's exclusive economic zones (EEZ). Coastal countries are not sovereign in these zones, but have sovereign rights over resources of the water column, on the sea bed and under the seafloor.

Arctic countries have sovereign rights over the continental shelf. Article 76 of UNCLOS claims that a country's continental shelf can extend 350 nautical miles $(648 \mathrm{~km})$, but cannot exceed 100 nautical miles from a 2,500 metre isobath measuring depth. Moreover, the continental shelf must be a natural geological extension of the land territory over which the state has sovereignty. This convention's clauses are subject to a large number of controversies and disagreements between states seeking to extend their area of jurisdiction in the Arctic. ${ }^{(36)}$

Disputes have emerged regarding the scope of such sea spaces and states' claims over the extension of the continental shelf to the ridges of Lomonossov and Mendeleïev. Many sources have misleadingly estimated that the latter might contain more than one fourth of the world's gas reserves. ${ }^{(37)}$ In reality, no reliable inventory of Arctic resources has been conducted to this day and it is estimated that all continental shelves contain only 30 percent of undiscovered gas resources and 13 percent of undiscovered oil reserves. ${ }^{(38)}$ Furthermore, nearly 95 percent of these reserves are found within EEZs. ${ }^{(39)}$ Hence, based on the current state of research findings, hydrocarbon fields on continental shelves would actually remain significantly limited. ${ }^{(40)}$

Beijing's declarations with respect to hydrocarbon deposit drilling in the Arctic are vague and as yet infrequent. As such, in his overview of China's activities in the region, the director of the political and planning division of the Chinese Arctic and Antarctic Administration, Xu Shijie, excluded the drilling of hydrocarbon deposits from China's future foreign policy objectives in the Arctic. Mr. Xu had earlier affirmed, "Since there is no reliable information on oil and gas reserves in the Arctic, China's interest in the latter region is primarily oriented around climate change. Whatever policy position China adopts on the matter will necessitate information about the Arctic's mineral and oil potential." (41)

The Chinese government does not deny its interest in the opening of new trade routes in the Arctic Ocean. Exports play a crucial role in China's economic development, and access to new trade routes in the Arctic would allow China to reduce its dependency on the Strait of Malacca. ${ }^{(42)}$ While Beijing emphasises openly the significance of such potential future routes for its economic growth and security in the years to come, it nevertheless acknowledges that navigation in these waters requires the approval of relevant Arctic countries, including Russia and Canada. ${ }^{(43)}$

Several scholars in mainland China have maintained that the international community must respect recommendations by UNCLOS, and that zones bordering Arctic countries should be open to all countries. ${ }^{(44)}$ Such a change could facilitate China's access to the Arctic. More particularly, Admiral Zhuo Yin has been cited frequently since he stated that "the Arctic belongs to all people of the world and no states should have sovereignty rights over it." (45) The admiral nevertheless failed to specify which sea spaces his comment referred to. Moreover, it remained unclear whether Zhuo Yin's radical stance published by the China News Service Agency also represented the official position of the Chinese government.

33. See for example, Du Mingjun, Ma Guiyang, Chen Xiaohan, "Bingtuqu maidi reyou guandao tingshu wenjiang shuzhi mosi" (Digital simulation of temperature plunges in a warm pipeline in permafrost areas), Tianranqi yu shiyou (Natural gas and oil), vol. 28, no. 4, 2010, pp. 54-57.

34. Linda Jakobson, "China Prepares for an Ice-Free Arctic," art. cit., p. 2.

35. Ren Xiaowei, LiYongqiang, "Beibingyang zhuquan zhi jue yu Zhongguo guoji zeren xianxi," art. cit., p. $66 \mathrm{ff}$.

36. Aleksandr Davidenko, "Neftegazovie i gazovie terminali. Novostroiki" (Oil and gas terminals: New sites), Morskye porty (Sea ports), vol. 79, no. 8, 2009, pp. 18-23; Hannes Gerhardt, Philip E. Steinberg, Jeremy Tasch, Sandra J. Fabiano, Rob Shields, "Contested Sovereignty in a Changing Arctic," Annals of the Association of American Geographers, vol. 100, no. 4, 2010, pp. 992-1002; Kristin Bartenstein, "Le fond marin arctique: convoitises et confusions" (The Arctic seabed: Covetousness and confusions), in Frédéric Lasserre (ed.), Arctic Corridors and Seas: Geopolitics of a Region Undergoing Change, 2010, Quebec, PUQ, pp. 291-318.

37. Timo Koivurova, "Alternatives for an Arctic Treaty - Evaluation and a New Proposal," Review of European Community \& International Environmental Law, vol. 17, no. 1, 2008, pp. 14-26.

38. United States Geological Survey, Circum-Arctic Resource Appraisal: Estimates of Undiscovered Oil and Gas North of the Arctic Circle, 2008, http://pubs.usgs.gov/fs/2008/3049/fs2008-3049.pdf (consulted on 8 August 2012).

39. Yves Mathieu, Institut Français du Pétrole (French Oil Institute), cited by the Nouvel Observateur, "Sauver le pôle Nord" (Save the North Pole), 12 March 2009; "Les réserves en hydrocarbures de l'Arctique" (Hydrocarbon reserves in the Acrtic), 2009, http://www.ifpenergiesnouvelles.fr/espacedecouverte/tous-les-zooms/les-reserves-en-hydrocarbures-de-l-arctique_1 (consulted on $8 \mathrm{Au}$ gust 2009); "Pas de pétrole sous le pôle Nord" (No gas under the North Pole), Sciences \& Avenir, October 2007.

40. Frédéric Lasserre, "Mines et pétrole.Vers une rapide expansion de l'exploitation des ressources naturelles du sous-sol dans l'Arctique?" (Mines and oil:Towards a rapid expansion of the extraction of natural resources in the Arctic's seabed), in Frédéric Lasserre (ed.), Passages et mers arctiques. Géopolitique d'une région en mutation (Arctic corridors and seas: Geopolitics in a region undergoing change), 2010, Quebec, PUQ, pp. 373-410.

41. Xu Shijie, Chinese Arctic and Antarctic Administration - China's Activities and Prospecting in the Arctic, Presentation given at the Centre for Foreign Policy and Security, Conference on "China and the Arctic," 30 April 2012, Montreal, Canada.

42. As the shortest route between the Indian and Pacific Oceans, the Strait of Malacca is one of the most commonly used corridors in the world. It has become the world's commercial hotspot for energy resources and other goods.

43. Lu Jinyuan, Beiji diyuan zhengzhi yu zhongguo yingdui (Geopolitics in the Arctic and China's response), Beijing, Shishi chubanshe, 2010.

44. Zhao Yun, "Xianxi Beiji suomian linde falü tiaozhan jiqi dui woguo de yinxiang" (An analysis of legal challenges in the Arctic and its impact on China), Haiyang kaifa yu guanli (Ocean development and management), vol. 26, no. 3, 2009, pp. 17-21; Liu Huirong, Dong Yue, Hou Yijia, "Baozhang woguo Beiji kaocha ji xiangguan quanyi falü chushen" (A legal approach to protect and defend the interests and rights of China in the Arctic), Zhongguo haiyang daxue xuebao, no. 6, 2010, pp. 1-4.

45. Cited by Gordon Chang, "China's Arctic Play," art. cit. 


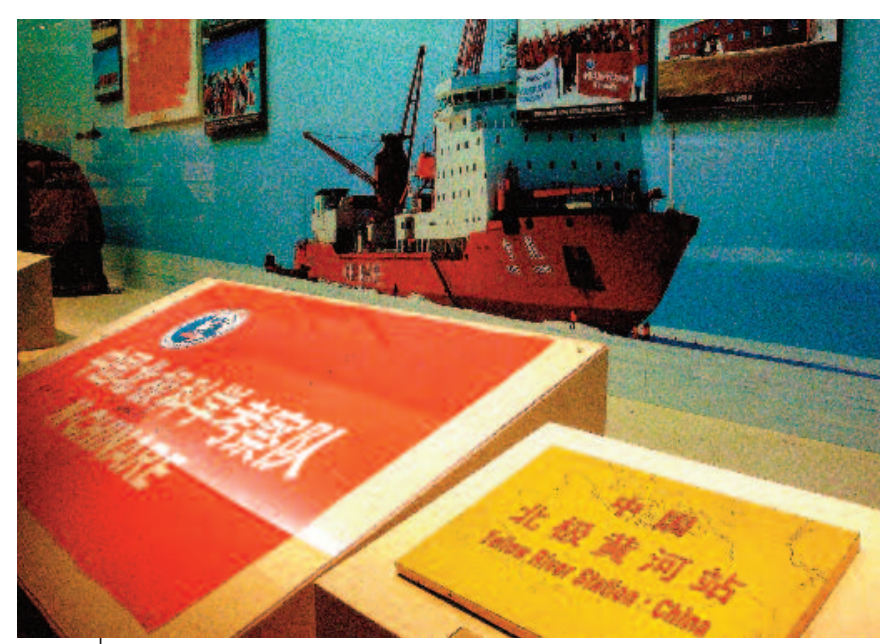

Picture 2: China's Arctic Exploration display, National Museum of China, Beijing, 14 December 2012. (c) Olga Alexeeva

In spite of the obvious absence of any officially articulated stance on the part of China, Beijing's growing interest in the Arctic is reflected in a large number of mainland Chinese scholars' unrestrained discussions on the subject. ${ }^{(46)}$ Many embrace the hypothesis that Arctic ice floes will have melted entirely by 2030 and believe that China should push forward its policy in an upcoming international struggle over control of the Arctic. Priorities are given to the extraction of natural resources and access to the new economic opportunities that a new trade route would generate in the region. As such, according to Li Zhenfu, a professor from Dalian Maritime University, "Those who will control navigation in the Arctic will also control future opportunities for economic development and international decisions." (47)

Mainland Chinese scientists have encouraged their government to change its position of neutrality and passive attitude vis-à-vis the Arctic by taking part in the process of delineating the areas of sovereignty and sharing of natural resources in that part of the world. These scholars have nonetheless failed to specify on what legal grounds such a policy would be conducted. According to the director of the Centre for Strategic Studies at the Polar Research Institute of China, "Being one of the largest energy consumers, China must improve its status in the Arctic and explore cooperation opportunities proactively with countries in the region. [...] Based on International Law, the Arctic does not belong to any particular country [...]. However, countries bordering the region have ambitiously sought to expand their influence in that part of the world, which until now has been free. [...] China must thus turn to the international community and show its capacity and determination to defend its interests in the area of natural resource extraction and the development of trade routes in the Arctic." (48)

Such bold opinions on the part of mainland researchers have been published not only in conventional academic journals but also in newspapers, usually known for refraining from publishing opinion pieces that are unauthorised ahead of time. The Anglophone journal of the China Institute of International Studies under the Ministry of Foreign Affairs published an article on China's stakes in the Arctic, in which the authors provide a detailed justification for China's right to take part in Arctic affairs, and urge the Chinese government to formulate a coherent policy in that regard. ${ }^{(49)}$ According to investigators from the School of International Relations and Public Affairs at Fudan University in Shanghai, the Chinese government must "develop a

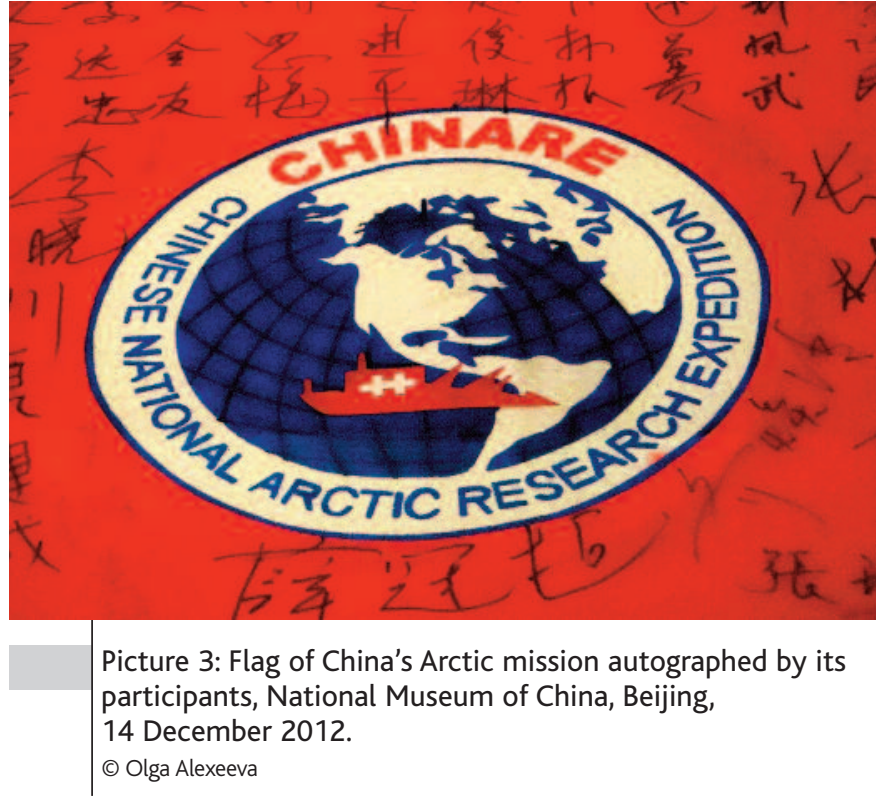

holistic approach and a well defined national strategy in the Arctic in the medium and long-term; [it must] include the protection and expansion of China's interests and rights in the Arctic in the country's overall develop strategy." (50)

In China, where published information is monitored (and if necessary, censored) by the Central Propaganda Department of the CCP, all articles must go through an editorial and political filter prior to publication in the pages of magazines and newspapers. ${ }^{(51)}$ The fact that bold and incautious opinions by mainland investigators about China's strategy in the Arctic have been authorised in national newspapers and major academic journals could be indicative of Beijing's willingness to become an active player in the region. The increase in such articles in the print media and Chinese news websites might also be part of an attempt to prepare public opinion for this possibility. Furthermore, the government has allowed a section of the National Museum's permanent exhibition to be dedicated to China's exploration of the Arctic (see picture 2). The exhibition is entitled "The Road to Revival" (fuxing zhi lu 复兴之路) - and provides an overview of the development of the revolutionary movement in China since the nineteenth century, summarising the Chinese people's great accomplishments under the guidance of the CCP. The exhibition's stand on the Arctic and Antarctic is located between those on China's space program and nuclear weapon testing. This

46. Li Zhenfu, "Diyuan zhengzhi zhili lilun yanbian yu Beiji hangxian diyuan zhengzhi lilun jiashe" (The Evolution of geopolitical theory and geopolitical hypotheses on Arctic maritime routes), Shijie Dili Yanjiu, vol. 19, no. 1, 2010, pp. 6-13; Zhang Shengjun, Li Xing, "Zhongguo nengyuan anquan yu Zhongguo Beiji zhanluë dingwei" (China's energy security and geopolitical position in the Arctic), Guoji guancha (International review), no. 4, pp. 64-71.

47. Linda Jakobson, "China Prepares for an Ice-Free Arctic," art. cit., pp. 6.

48. See Zhu Shanshan, "Arctic competition heats up as ice melts," Global Times, 2011, www.globaltimes.cn/NEWS/tabid/99/articleType/ArticleView/articleld/666783/Arctic-competition-heatsup-as-ice-melts.aspx www.globaltimes.cn/NEWS/tabid/99/articleType/ArticleView/articleld 1666783/Arctic-competition-heats-up-as-ice-melts.aspx(consulted on 7 August 2012); "Arctic nations should warm to other powers," Global Times, 2011, www.globaltimes.cn/NEWS/ tabid/99/ID/669098/Arctic-nations-should-warm-to-other-powers.aspx (consulted on 7 August 2012).

49. Qin Qian, Chen Yugang, "The Post-Cold War International Cooperation in the Arctic Region," China International Studies, September/October Issue, 2011, pp. 138-155.

50. Ibid, pp. 154

51. Dominique Colomb, Médias et communication en Chine. Au-delà des paradoxes (Media and communication in China: Beyond paradoxes), Paris, L'Harmattan, 2008. 
suggests the symbolic significance given to China's activities in the Arctic The museum is free of charge and attracts 4 million visitors annually. It is not only a window on China but also constitutes a significant instrument of political and historical education. ${ }^{(52)}$

It would be surprising for mainland Chinese investigators' position on China's strategy in the Arctic to become official. Historically, Beijing has emphasised the principle of non-interference in third parties' claims over territorial sovereignty. Since the 1950 s, this principle had become very popular among newly independent states liberated from colonisation. China has justified its rejection of third-party interference by emphasising the destructive effects of foreign intervention in the economic and political affairs of other countries. ${ }^{(53)}$ In spite of its emphasis on non-interference, China claims that straits stretching from north to west in the Arctic are international property. If so, Canada could make a similar statement, affirming that the Qiongzhou Strait, located between Hainan and mainland China, also belongs to the international community. China nevertheless denies that. Similarly, Beijing has sought to justify its claims over the South and East China seas. If the extension of China's maritime access in Asia is legitimate, why would that of Canada and other bordering countries in the Arctic not be?

As such, although Vice-Minister of Foreign Affairs Hu Zhengyue declared that "China did not have a policy towards the Arctic" during a conference held in Spitsbergen in November 2009, (54) local sources suggest that China is developing a well-defined strategy to further its interests in the region. The latter would comprise the following four components:

1. Strengthening scientific field research to legitimise China's growing presence in the region;

2. Developing relations with countries neighbouring the Arctic Ocean;

3. Consolidating coordination between non-Arctic countries to find common interests to defend and promote internationally in the region;

4. Developing a strategy towards the North and making it a part of China's global development program.

The above components constitute only the broad lines of China's policy towards the Arctic. The details of the policy, along with its short- and longterm objectives, practical implications, and geopolitical consequences, have yet to be fleshed out. At the very least, China seems determined to challenge sovereignty claims over the maritime space of countries neighbouring the Arctic Ocean.

\section{Sino-Russian cooperation in the Arctic}

While China is not a circumpolar state, it nevertheless seeks to develop closer ties with countries neighbouring the Arctic by strengthening its economic and geopolitical presence in the region. A series of agreements signed with Denmark and Iceland since 2000 are indicative of Beijing's increasingly explicit interest in countries that could become important centres in the Arctic's maritime transit zones in the long run. Similar motivations are at the heart of China's relations with Russia, which controls Arctic transit from north to east and plans to explore natural resources in the Arctic zone. The development of energy cooperation with Russia in the region constitutes one of Beijing's priorities. Such cooperation would provide China with legitimate access to the Arctic, including trade routes and natural resource extraction opportunities. According to mainland Chinese experts, Russia would constitute one of the main points of entry for Chinese companies wishing to explore the Arctic's energy and maritime access opportunities in the near future. ${ }^{(55)}$ The Chinese government has already signed a certain number of cooperation agreements with some Russian Arctic regions. For instance, in Yakutia, located in the northeast of Siberia, China is financing the opening of a trade corridor through the Northeast Passage between the Ziryanka coal mine in the district of Verkhoyansk and Shanghai. In the shortterm, the new corridor will allow Russia to provide China with 60,000 tons of coal annually. ${ }^{(56)}$ While this volume represents a very small proportion of China's total coal consumption, the initiative nonetheless reflects China's efforts to deepen its relations with Russia and Yakutia's search for new commercial openings. China attributes significant importance to its energy and economic partnership with Russia in the Arctic zone. The following discussion delves into the details of such cooperation.

The broad lines of Sino-Russian cooperation were defined in the SinoRussian Treaty of Good-Neighborliness, Friendship and Cooperation signed in 2001. This agreement marked both countries' willingness to ensure each other's security and mutual trust, and to undertake cooperative initiatives based on the principle of reciprocity, especially in the energy sector. ${ }^{(57)}$ The last agreement signed between Russian President Dmitry Medevdev and Chinese President Hu Jintao on 23 September 2009 was also meant to strengthen both countries' economic cooperation. The agreement entitled "Program of Cooperation between the Regions of the Far East and Eastern Siberia and the Northeast of the People's Republic of China, 2009-2018" includes 205 major bilateral projects meant to bring Sino-Russian cooperation to a higher level than ever before.

All the projects on Russian territory pertain to the extraction of deposits of all kinds, including coal, iron ore, precious metal remains, apatites, and molybdenum in Eastern Siberia. The extraction of raw materials will be financed by Chinese funds and conducted by a mainland Chinese labour force. The latter will come from the north-eastern provinces neighbouring Russia, which have been greatly affected by unemployment as a result of the shutdown of many state-owned enterprises. Once extracted, raw materials will be transported to China's north-eastern region and transformed into end products. The Chinese government will create a large number of factories in China specialising in the production of tin, lead, copper sheets, bricks, etc. As such, Sino-Russian cooperation in the next ten years will involve the exchange of Russian raw materials with Chinese funds, technology, and labour. Sino-Russian cooperation projects in the Arctic will follow a similar logic

52. "National Museum of China officially opens to public," Xinhua, 2012, http://news.xinhuanet.com/ english/china/2012-03/01/c_131440701.htm (consulted on 7 August 2012); Brice Pedroletti, "Les expositions du musée national de Chine détournent l'histoire" (The exhibitions of the National Museum of China distort history), Le Monde, 2012, www.lemonde.fr/culture/article/2011/04/ 11/les-expositions-du-musee-national-de-chine-detournent-l-histoire_1506084_3246.html (consulted on 7 August 2012).

53. For more information about the evolution of China's foreign policy, see for instance Li lie, "Reflections on the New China's Diplomacy in the Past Sixty Years," China International Studies, no. 18, 2009, pp. 4-30.

54. Linda Jakobson, "China Prepares for an Ice-Free Arctic," art. cit., pp. 9.

55. Li Jingmei, Shao Zijun, Fang Dianyong, Wang Xinran, "Beijiquan youqi ziyuan qianli fenxi" (An analysis of the Arctic Circle's gas and oil potential'), Ziyuan yu chanye (Resources \& industries), vol. 12, no. 4, pp. 29-33.

56. "Jakutia, ugol' i Severnyj morskoj put'"(Yakutia, coal and transit in the northeast), Neftegaz.ru, 2012, http://neftegaz.ru/news/view/102170 (consulted on 10 May 2012).

57. Isabelle Facon, "Les relations Chine-Russie vues de Moscou: variable de la politique étrangère ou réel partenariat stratégique ?" (Sino-Russian relations from the perspective of Moscow:A genuine strategic partnership?), Cahiers de Mars, no. 183, 2005, pp. 100-110. 
and are crucial components of each country's foreign policy. Russia seeks to diversify its oil consumers to reduce its dependency on the West. ${ }^{(58)}$ In order to reach these objectives, Moscow must not only develop a transportation network on its territory and open alternative trade routes, but also start extracting rich deposits in its Arctic zones, including in the Yamal Peninsula. The latter would eventually replace existing sources of extraction in Siberia that are in decline. ${ }^{(59)}$ As such, Russia's Gazprom plans to start extracting before $2030 \mathrm{a}$ certain number of offshore deposits in the Arctic, including in the Barents, Okhotsk, Kara, and Pechora seas. These projects will enable the country to increase its gas production by 11 billion tonnes of oil equivalent. ${ }^{(60)}$ From the perspective of Beijing, eager to intensify and diversify its imports of hydrocarbon resources for economic growth purposes, Russia constitutes an ideal provider due to its proximity and the abundance of its oil and gas deposits. China's interest in taking an active part in most of Russia's energy-related projects at the national and regional levels supports claims that the Russian and Chinese economies supplement one another. ${ }^{(61)}$

In 2009, the Russian state oil company Rosneft announced the launch of a project of development and extraction of 30 new oil sites in the Arctic and offshore zones. Nevertheless, the company needs funding for the project. It also requires the oil extraction technology to drill to the bottom of deep oceans in extreme climate conditions and areas that are hard to access. ${ }^{\left({ }^{2} 2\right)}$ Russia is particularly lagging behind in this area compared with oilrich Western countries. ${ }^{(63)}$ These considerations have pushed Moscow to search for partnerships abroad, including in China. Three Chinese companies have offered to provide the necessary resources and labour: China National Petroleum Corporation, China National Offshore Oil Corporation, and China Petroleum \& Chemical Corporation Limited. According to the Russian media, bilateral discussions are currently taking place to establish to what extent China will participate in the project.

Most of the oil and gas Russia plans to extract in the Arctic will target the Asian market, and most particularly China. ${ }^{(64)}$ Oil transportation will thus be at the core of Sino-Russian discussions. ${ }^{(65)}$ Relevant deposits are not yet connected to Russian pipeline systems, but the Russian companies Transneft and Gazprom plan to build some in the future. ${ }^{(6)}$ The need to build adequate infrastructure and facilities (i.e., specialised refineries for heavy crude oil) to transform oil into marketable products prompted Russia to study more closely the potential opening of new navigation routes in the North. ${ }^{(67)}$ The first time Russian oil was shipped to China through the Northern Sea Route was in August 2010. Tanker Baltica was accompanied by an icebreaker and took 27 days to deliver 70,000 tons of natural gas condensate from Murmansk to Ningbo, a city located in north-eastern Zhejiang Province.

This first attempt was followed by the signing of a long-term cooperation agreement in the area of Arctic navigation between Russia's shipping company Sovcomflot and China National Petroleum Corporation in November 2010. This agreement was officially declared an integral part of China and Russia's strategic energy cooperation, and was signed in the presence of Igor Sechin, Deputy Prime Minister of the Russian Federation and symbolic President of Rosneft's management board, as well as Wang Qishan, Vice-Premier of the State Council of the People's Republic of China. This agreement specifies the procedures behind the joint usage of the Northeast Passage for transit or oil transportation purposes. In 2011, many bulk carriers transported iron ore from Murmansk and Kirkenes (Norway) to Chinese ports by going through the Northern Sea Route, and many other ships transported methane and oil between Vitino and China. More than 600,000 tons of con- densate were exported to Asia via the Northern Sea Route in 2011.(68) Beyond the diversification of opportunities for transit, China is interested in the access to natural resources that the Arctic may provide. ${ }^{(69)}$

The Maritime Administration of the Russian Federation plans to launch a new large-scale national program, the objective of which would be to create favourable conditions for the use of a new transport corridor in the near future. ${ }^{(70)}$ The program involves several steps:

- The development of port facilities along the Northern Sea Route (ports of Indiga, Pechenga, and Varandey on the coasts of the Barents Sea, port facilities in the Yamal Peninsula, etc.) and modernisation of existing ports (Khatanga, Tiksi, Pevek, Dudinka, and Dikson);

- The repair of existing Russian Arctic vessels and construction of a series of new-generation icebreakers, including some nuclear-powered polar models;

- The conduct of large-scale hydrographic work to collect precise technical and geographical information to ensure safe navigation in relevant Arctic zones;

58. Guillaume Mascotto, "Entre intérêt mutuel et méfiance: les relations énergétiques sino-russes" (Between mutual interest and suspicion: Sino-Russian relations in the energy sector), Cahiers de Recherches - CEIM, 2009, www.ieim.uqam.ca/IMG/pdf/chine.energie.pdf consulted on 7 July 2012).

59. In average, about $50 \%$ of resources have already been extracted in Siberia's known oil deposits, $70 \%$ in those of Ural, and $65 \%$ in those of the European part of Russia. Gas deposits in old extraction locations (i.e., regions of Krasnodar, Stavropol, lower Volga area) have been used up to $80-90 \%$, while $40 \%$ of resources have been extracted from Siberia deposits. See V. Podolskiy, O. M. Priščepa, "Neftegazovyj potencial Rossii. Sovremennoe sostojaanie, perspektivy razvitija" (The oil and gas potential of Russia: The current state of development), Neftegazovaya geologia. Teoria i praktika (The geology of oil and gas: Theory and practice), no. 2, 2007, pp. 1-23.

60. "Gazprom planiruet do 2030g prirastit' zapasy v Arktike na $11 \mathrm{mlrd}$ t uslovnogo topliva" (Gazprom plans to raise resource extraction in the Arctic before 2030 up to 11 billion tonnes of oil equivalent), Sever - naš! (The Arctic belongs to us!), 2011, http://preview.severnash.ru/economics/energy/3014-gazprom-planiruet-do-2030g-prirastit-zapasy-v-arktike-na-11-mlrd-t-uslovnogo-topli va.html (consulted on 7 August 2012).

61. Chinese investigators emphasise that for many years, China has provided the Russian market with all kinds of consumer products, while Russia exports to China raw materials necessary for the development of the Chinese economy, primarily based on the production of everyday consumer goods. Moreover, China sends Russia thousands of workers to help reconstruct and develop the Russian economy. Given both countries' economic interdependency, their geographical proximity and close historical and political ties, China and Russia's economies increasingly supplement each other. See Chen Xianling, "Zhong-E nengyuan hezuode xianzhuang qianjing fenxi ji qishi," (Current state, analysis and observations on Sino-Russian energy prospects), Xiboliya yanjiu vol. 37, no. 3, 2010, pp. 22-28; Xing Guangcheng, "Deepen the Meaning of Sino-Russian Strategic Partnership of Coordination," China International Studies, September/October Issue, 2011, pp. 156-177.

62. Aleksandr Davidenko, "Neftegazovye i gazovye terminali. Novostrojki", pp. 19 ff.

63. S. B. Savel'eva, G. N. Šiyan, "Arktika: ukreplenie geopolitičeskih pozitsij i èkonomičeskoe razvitie" (The Arctic: Strengthening geopolitical positions and economic development), Vestnik MGU (State Moscow University Press), vol. 13, no. 1, pp. 115-119.

64. V. A. Popov, "Perspektivi razvitiya portov Arktiki i Severnogo morskogo puti" (Development prospects of Arctic and northern sea ports), Razvitie portov (Port development), no. 5, pp. 12-15; Strategia razvitiya arktitcheskoi zony Rossiĭskoi Federatsii i obespechenie natsional'noi bezopasnosti na period do 2020 goda (The Russian Federation's development strategy for the Arctic Zone and national security until 2020), http://narfu.ru/aan/institut_arctic/strategy_AZRF_2010.pdf (consulted on 8 August 2012).

65. Osnovnie položenija strategii morskoj dejatelnosti Rossijskoj Federacii do 2020 goda i na bolee otdalennuju perspektivu (The main facets of the Russian Federation's navigation strategy until 2020 and in the long-run), Moscow, SOPS, 2009.

66. V. A. Popov, art. cit., p. 13.

67. V. I. Hodirëv, E. K. Blinov, "Èkspluatacia Severnogo morskogo puti - ètap sovremennogo innovacionnogo razvitija Rossii" (The exploitation of the Northern Sea Route - An important step for Russia's current development), Gosudarstvo i transport (State and transport), vol. 20, no. 1, 2009, pp. 4-6.

68. "Less Russian Oil Around the Coast of Norway," BarentsObserver, 1 December 2011.

69. Frédéric Lasserre, Sébastien Pelletier, "Polar super seaways? Maritime transport in the Arctic: An analysis of shipowners' intentions," Journal of Transport Geography, no. 19, 2011, pp. 1465-1473.

70. "Osnovi gosudarstvennoj politiki Rossijskoj Federacii v Arktike na period do 2020 goda i dal'neishie perspektivy" (The main facets of the Russian Federation's navigation strategy until 2020 and in the long-run), Rossijskaja gazeta (Russian journal), 30 March 2009. 
- The modernisation of the emergency intervention system in Arctic waters and the creation of a research and rescue centre in Tiksi, to monitor navigation zones and coordinate rescue operations. ${ }^{(71)}$

China has expressed interest in being part of the above program and broadening its cooperation with Moscow in the Russian Arctic zone. ${ }^{(72)}$ Among the proposals made by Beijing is its financial support of the opening of navigation routes in the Arctic, the identification and evaluation of natural resource reserves in the region, and scientific cooperation. China will participate in the construction and launch of floating nuclear plants in the Arctic. The latter will be placed along sea and river shorelines to provide newly built ports and commercial bases along the Northeast Passage with necessary energy. ${ }^{(73)}$

The Chinese government hopes that Russia will authorise Chinese scientific aircraft to fly over its territory in the Arctic and enable its scientists to work in Russian Arctic stations. ${ }^{(74)}$ However, the potential for Sino-Russian cooperation in the area of natural resource extraction in the Arctic triggers several questions. How far have China and Russia actually cooperated in the Arctic up to now? Will Russia be able to implement its ambitious Arctic development program? What would be China's actual role in that process? Would the program result in the extension of both countries' strategic partnership or translate into a new bilateral agreement of some kind? Vladimir Putin, who was recently re-elected as Russia's President, seems determined to orient Russia's foreign policy in the latter direction by promoting the development of Sino-Russian ties and joint cooperation in the Arctic. As such, the first official visit by Putin following his re-election as President was to China in June 2012.

\section{Conclusion}

In spite of China's growing presence in the Arctic and its past implementation of research projects in the area, Beijing only recently and implicitly expressed claims over access to the region. China has gradually developed and implemented a coherent policy to secure its interests in that region.
On the one hand, it has launched a vast scientific polar research program and promoted the diffusion of knowledge about the Arctic for policy-related purposes. On the other hand, it has established durable economic and political relations with circumpolar countries by taking an active part in international debates about the Arctic and its role in world development. Ultimately, China has succeeded in becoming one of the main actors on the Arctic scene in spite of its lack of geographical access to the region. China's priorities reveal its rising international ambitions to be heard on matters pertaining to Arctic governance and to have access to the region's natural resources through market mechanisms, questions that remain the heart of disagreements between Russia and Canada.

Many questions regarding China's role and interest in the Arctic have yet to be answered. Whether mainland Chinese scientists' positions on China's involvement in the region are also those of the Chinese government requires clarification. Moreover, what are the practical implications and consequences of Beijing's strategy towards the Arctic? Are there undisclosed facets of Beijing's policy towards the region? Is the policy in line with China's other geopolitical and energy-related priorities? More quantitative and qualitative data is needed to answer these questions, better grasp China's Arctic strategy, and anticipate its evolution in the near future. These questions are at the heart of our current research and will be the object of our next fieldwork trips in China.

\section{Iranslated by Marie-Eve Reny.}

I Olga V. Alexeeva is a professor of Chinese History in the Department of History at the University of Quebec in Montreal (UQAM).

Université de Québec à Montréal, Département d'histoire, Pavillon Hubert Aquin, 400 rue Sainte-Catherine Est, Montréal, Qc, H2L 2C5 (alexeeva.olga@uqam.ca).

I Frédéric Lasserre is Director of the ArcticNet Project in the Department of Geography at Laval University, Quebec.

Département de géographie, Pavillon Abitibi Price, 2405 rue Terrasse, Université Laval, Québec, QC, G1V 0A6 (frederic.lasserre@ggr.ulaval.ca).
71. Ibid.

72. Tatiana Pičugina, "Kitaici rasskazali o planah po izučeniu Arktiki" (The Chinese reveal their plans in the Arctic), Nauki i Tehnologii RF (Russian Federation's sciences and technologies), 2011, http://www.strf.ru/material.aspx?Catalogld=222\&d_no=41978 (consulted on 8 August 2012).

73. Artem Gončaruk, "Drugoe sotrudničestvo" (Another cooperation), ChinaPRO, 2012, www.chinapro.ru/rubrics/2/7609 (consulted on 8 August 2012); Kitaj i Rossia postrojjat plavučie AES dlja Krajnego Severa (China and Russia will build floating nuclear plants flottantes for the Arctic), Sever - naš! (The Arctic is ours!), 2011, http://preview.severnash.ru/economics /energy/2867-kitay-irossiya-postroyat-plavuchie-aes-dlya-kraynego-severa.html (consulted on 10 May 2012).

74. Tatiana Pitchugina, art. cit. 